\title{
Why no Cohabitation in Taiwan?
}

An analysis of Taiwan's Constitution and its application

\section{Da-Chi Liao et Herlin Chien}

\section{OpenEdition}

\section{Journals}

Édition électronique

URL : http://journals.openedition.org/chinaperspectives/466

DOI : $10.4000 /$ chinaperspectives.466

ISSN : 1996-4617

Éditeur

Centre d'étude français sur la Chine contemporaine

Édition imprimée

Date de publication : 1 avril 2005

ISSN : 2070-3449

\section{Référence électronique}

Da-Chi Liao et Herlin Chien, « Why no Cohabitation in Taiwan? », China Perspectives [En ligne], 58 | march - april 2005, mis en ligne le 01 avril 2008, consulté le 28 octobre 2019. URL : http:// journals.openedition.org/chinaperspectives/466 ; DOI : 10.4000/chinaperspectives.466

Ce document a été généré automatiquement le 28 octobre 2019.

(c) All rights reserved 


\title{
Why no Cohabitation in Taiwan?
}

\author{
An analysis of Taiwan's Constitution and its application \\ Da-Chi Liao et Herlin Chien
}

1 After the Sixth Legislative Yuan election on December 11th 2004, Taiwan's political arena was, once again, resounding with the debate on adopting French-style cohabitation $^{1}$. The revision of the Constitution of the Republic of China (ROC) in $1997^{2}$ gave the ROC President the power to appoint the Premier of the Executive Yuan without the consent of the Parliament. Thus the Taiwan political system, constitutionally speaking, resembles more the French semi-presidential system in the Fifth Republic, than the US-style presidential system. However, despite this strong resemblance, the systems are distinct. While France has experienced three cohabitations-in 1986, 1993 and 1997-, how is that Taiwan has not taken the same route? Does the ROC Constitution require cohabitation when the President has lost majority support in Parliament? What has prevented cohabitation since President Chen Shui-bian's election in $2000^{3}$ ?

Constitutional framework

2 In general, there is consensus among scholars that Taiwan's political system resembles the dual-executive or what Maurice Duverger termed the semi-presidential system of the Fifth Republic in France ${ }^{4}$. Duverger defines three conditions for a constitutional system to be termed "semi-presidential" 5: the President is directly elected for a fixed term; the President possesses quite considerable powers; and, the Constitution grants both the head of state-the President-and the head of the government-the Prime Minister-to share executive power ${ }^{6}$. France, after its 1962 Constitutional reform, which created a directly elected President by a popular vote, and Taiwan, with its Constitution amended in 1997, which authorises the direct nomination of the Premier by the President without the consent of the Parliament, meet the first two of Duverger's three conditions ${ }^{7}$.

3 However, the political systems of France and Taiwan have, crucially, different constitutional requirements, in addition to the fact that the relationship between the executive and the legislature varies one from the other. The French Constitution is designed in such a way as to facilitate the emergence of cohabitation if the President 
does not have majority support in Parliament; whereas Taiwan's constitutional framework does not, whether the President has the support of the Parliament or not.

Articles 53 and 57 of the ROC Constitution state respectively that "the Executive Yuan shall be the highest administrative organ of the state" and "the Executive Yuan shall be responsible to the Legislative Yuan". Article 20 of the Fifth Republic Constitution of France, meanwhile, states that "the government determines and executes national policies. The government dictates administrative institutions and the use of the army. The government, under articles 49 and 50, is responsible for the Parliament". Later, Article 21 authorises the Prime Minister to direct actions of government. As such, by the legal framework, the executive branches in France and Taiwan ought to be responsible for the legislative branches.

5 In parallel, Presidents in Taiwan and the French Fifth Republic are given constitutional power to nominate the Prime Minister who is the head of the Executive branch of government. However, while a presidential order in Taiwan can actively remove the Premier from office without the countersignature of the Premier ${ }^{8}$, the President in the Fifth Republic only can passively grant the resignation of the Prime Minister along with dismissal of the government ${ }^{9}$. Legally then, in the event of a divided government where the President and the majority in Parliament are with different parties, the nominated French Prime Minister only needs to earn the support of the Parliament, once appointed, as the trust of the President is irrelevant due to the president having no active power of dismissal over the Premier. While the Premier in Taiwan must have the support of the President, as the power to dismiss the Premier remains in the hands of the President.

6 Article 49 of the Constitution of the Fifth Republic has no parallel in the ROC Constitution. According to this Article 49, the Prime Minister can request the National Assembly to cast a confidence vote, which legally prevents the emergence of a divided government in France thus favouring cohabitation ${ }^{10}$. Such a confidence vote, if supported by Parliament, can further legitimise the role of the Prime Minister as a counterbalance to the power of the President. In other words, in France, the situation of the President and the Prime Minister holding equal power is strengthened by Article 49. Such a footing can provide an incentive yet also a constraint for the President to choose cohabitation, rather than a divided government in which the Prime Minister might fail to gain the confidence vote of Parliament immediately after appointment. In Taiwan's system, the absence of this resort to a confidence vote not being prescribed in the Constitution, means there is no strong incentive to choose cohabitation ${ }^{11}$.

7 Furthermore, France and Taiwan have in place slightly different mechanisms where the crucial no-confidence vote, which can break executive-legislative gridlock and initiate a sprit of responsible politics in the parliamentary system, is concerned ${ }^{12}$. In Taiwan, if the legislature finds the Premier unacceptable, its only constitutional option is to undertake a vote of no-confidence in accordance with amendment article 3, which, if it passes, opens the door for the President to passively dissolve the legislature ${ }^{13}$. Therefore, under threat of being dissolved by the President, the legislature must think twice before issuing a vote of no-confidence which will lessen the leverage power of legislature on the Premier. As the President has the power to appoint or remove the Premier, cohabitation could be a possible option, but is not required by the Constitution. 


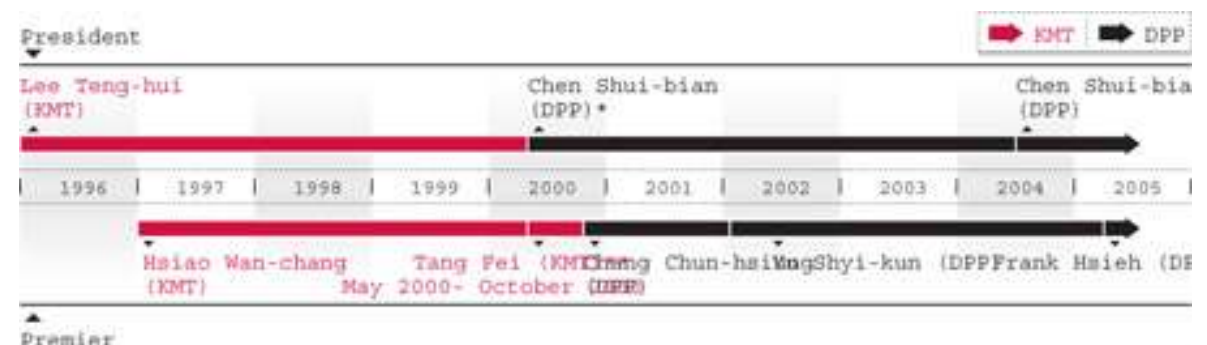

Premiex

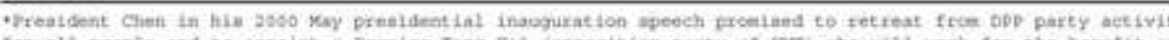

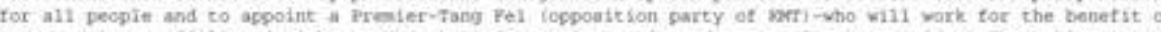

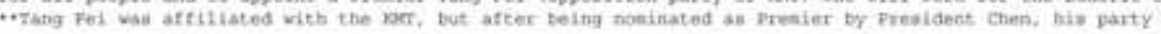

The rule is quite different in France, especially concerning the President's active right to dissolve the Parliament. Article 49 Section 2 of Fifth Republic Constitution rules that the National Assembly can propose a vote of no-confidence with more than a one-tenth vote of the total Parliament members. Due to the frequent issuing of no-confidence votes in the Third and Fourth Republics, Article 12 of the Fifth Republic Constitution grants the President the right to actively dissolve Parliament ${ }^{14}$. This rule may to a certain extent institutionalise the emergence of cohabitation through the presidential power if the President dissolves the Parliament and the re-election result of the new Parliament still forces the President to face an opposition majority ${ }^{15}$.

Constitutional practice

The purpose of analysing how the Constitution works in practice, of the gap between the written Constitution and its application, and of the dynamic interaction with psychological, social and cultural traits, is to explore why under a similar constitutional framework-a semi-presidential system-France has seen cohabitations and Taiwan up to now has not.

10 Constitutionally speaking, although the ROC President is granted the right to freely choose the Premier without the consent of Parliament, the Parliament can indirectly exert influence in the choice of the Premier via a threat of a vote of no-confidence. This could trigger a constitutional crisis, and a consequential retaliation by the President in dissolving the Parliament. If the above is followed, the ROC President could be constrained in his or her choice of Premier and, when facing strong opposition in Parliament, have no choice but to appoint an opposition Premier to lead the government, handing the major executive right to the Executive Yuan. However, this did not happen during 2000-2004, nor has it happened in the 2005 presidency, though President Chen Shui-bian faces a majority opposition in the Legislative Yuan (Table 2). Taiwan's political system is led by a strong President in a divided government.

\section{Party affiliation of legislators}

\begin{tabular}{|c|c|c|c|c|c|c|c|c|}
\hline & DPP & TSU & pors & PFP & NP & NPSU: & None+Other & Total \\
\hline 2004 & 89 & 12 & 79 & 34 & 2 & 6 & 4 & 225 \\
\hline 2001 & 87 & 13 & 68 & 46 & 1 & n.a. & $9+1$ & 225 \\
\hline 1998 & 70 & B.a. & 123 & n.a. & 12 & n,a. & $12+9$ & 225 \\
\hline 1995 & 54 & n. a. & 85 & A.a. & 21 & $\mathrm{n} \cdot \mathrm{a}$ & 4 & 164 \\
\hline $\begin{array}{l}\text { saurees Central } \\
\text { wi: The pan-aree } \\
\text { the people Yiret }\end{array}$ & $\begin{array}{l}\text { Alection Coon } \\
\text { en include th } \\
\text { Party. (FF) }\end{array}$ & $\begin{array}{l}\text { minajot, Tai } \\
\text { e Denocratic } \\
\text { and the liev }\end{array}$ & $\begin{array}{l}\text { was, } \\
\text { brogreasiven } \\
\text { Darty lap]. }\end{array}$ & 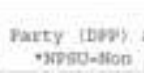 & $\begin{array}{l}\text { and the } T \\
\text { Partisan }\end{array}$ & $\begin{array}{l}\text { Falwan Sol } \\
\text { Bolidaris }\end{array}$ & $\begin{array}{l}\text { anrity thion th } \\
\text { tonion, n-a. }\end{array}$ & $\begin{array}{l}\text { Tath. The } \\
\text { - note a }\end{array}$ \\
\hline
\end{tabular}

The unfunctionality of the no-confidence vote 
11 The no-confidence vote mechanism design is originated from the parliamentary system and its purpose is maintaining a responsible politic, balance of power between government branches and resolving executive-legislative gridlock. However, the noconfidence vote mechanism has never been used in Taiwan, for legislators are unwilling to trigger its introduction unless urgently needed. Without a no-confidence vote, the President can continue with an opposition majority in Parliament: this has happened several times and appears to be becoming a constitutional routine.

What prevents legislators casting a vote of no-confidence is rooted in the electoral system of the multi-member district with a single-non-transferable vote (SNTV) in which legislators run for re-election at great risk ${ }^{16}$. In the SNTV, a voter has only one vote in a multi-member district and the vote is not transferable. Moreover, while each individual candidate need only obtain enough ballots to pass the threshold of exclusion to be elected, intra-party competition might be stiffer than inter-party competition during elections ${ }^{17}$. Every candidate must stand out, and closely watch his/her brokers and loyal supporters in order to avoid vote erosion ${ }^{18}$. So, if having been through a highly competitive election and having finally been elected as legislators, being rational actors, they would not easily cast a vote of no-confidence, which would be equivalent to giving up their legislative seat and gambling again on the next legislative re-election ${ }^{19}$.

Moreover, according to a recent survey, the average spend of a legislative candidate during a single election amounts to NT $\$ 42$ million ${ }^{20}$ which makes a no-confidence vote and the consequential re-election campaign for legislators very expensive and clearly less preferable. Therefore, without exercising a no-confidence vote, a divided government called by a Taiwan President can survive without considering cohabitation as an option ${ }^{21}$.

Lack of historical path dependence

14 Another factor that may prevent the emergence of cohabitation in Taiwan can be understood by the lack of any historical experience of any similar system in the past in Taiwan.

Taiwan, heavy with historical political experience, and Taiwan people, have a great expectation of the role of a President. Even the operation of the dual-executivenamely two rulers, the President and the Premier-, and prescribed in the semipresidential system of Taiwan, can hardly be accepted, even as a concept ${ }^{22}$. Taiwan has had 37 years of a highly centralised interim rule under a strong man and KMT rules, a period during which the Constitution, which permitted a balance of power, was suspended $^{23}$. One ruling organ-the President or the KMT-was for a long time the only source of authority and power for the government. Even after 1996 when President Lee Teng-hui was directly elected, his ruling style is characterised as "super-presidential". Former Premier Chang Chun-hsiung pointed out that "A President who can nominate the Premier without consent of Parliament, is not required to be responsible for Parliament, yet has the right to dissolve Parliament, is creating a powerful President without responsibility and a powerless Premier with responsibility ${ }^{24}$. What Taiwan people expect from a popular elected President exceeds the constitutional right a President can hold. The idea of a second ruler-the Premier to counterbalance the President or to co-rule with the President, has so far hardly found historical support in the Taiwan community. 

framework, yet the gap between the written Constitution and its practice reduces the likelihood of cohabitation in Taiwan. "Cohabitation", called for by the Pan-Blue camp, has never been seen in Taiwan, and there is still a way to go before it could be successfully implemented. The constitutional systems of the ROC and the French Fifth Republic are quite different. The unfunctionality of the no-confidence vote due to SNTV electoral rule and the high cost of winning the re-election are crucial to understanding why the rule of a divided government, over cohabitation, persists in Taiwan. Unlike France, where constitutional customs are already established and the concept of dual-executives continuously practiced, Taiwan does not have the experience that could provide a stable base for the establishment if a system that could embrace cohabitation.

Will Taiwan see cohabitation in the future? Based on the current formal constitutional arrangement, cohabitation may be unlikely to emerge in Taiwan. If adding constitutional practice, especially with the evolving power structure within the Legislature, President Chen is facing a different political environment than that faced by Lee Tung-Hui. During his first term, President Chen has tried to negotiate with Wang Ching-ping, the Speaker of Legislative Yuan, of the KMT opposition party. Under the current presidency, he has initiated communication with the opposition leader of the PFP, Soong Chu-yu. To a certain extent, political reality may lessen the strength of the President. However, if the current constitutional framework remains unchanged, the emergence of cohabitation is still unlikely in Taiwan's present context. The practices of sharing executive rights between two heads is still to be learned in Taiwan.

\section{NOTES}

1. Such a concept was initially proposed in the summer of 2001 by the People First Party (PFP) who seemed to have carefully analysed the political landscape and concluded that a "cohabitation à la française" was probably inevitable. Yet this was not what Chen Shui-Bian had in mind. See Berthier Serge, "Who Won the Legislative Election in Taiwan?", Asian Affairs, December 2001. Lien Chan, Chairman of the Kuomintang (KMT), proposed at the 2004 Taipei Roundtable Meeting of December 16th with representatives from the Center for Strategic and International Studies (CSIC), that President Chen should respect the new majority in Parliament by forming a new cabinet and consider nominating an opposition member, Deputy Legislative Speaker Chiang Pin-kun, as the new Premier.

2. The 1947 Constitution of the Republic of China (ROC) has been revised six times. In the third revision of 1994, the ROC President is to be elected directly by popular vote, starting from 1996. The fourth revision of 1997 introduced the nomination of the Premier by the President and the parliamentary vote of no-confidence.

3. The 2000-2004 and 2005-2008 pan-green Democratic Progressive Party (DPP) Chen Shui-bian presidency is facing pan-blue opposition majority in the Parliament.

China Perspectives, 58 | march - april 2005 
4. As the President is to be elected by a popular vote directly with his/her party, then often referred to as the ruling party, some people have compared the Taiwanese system to the US-style presidential system. Lin Chia-chen, former president of the Research, Development, and Evaluation Commission of the Executive Yuan, offered such comment in Zhongguo shibao (China Times), on October $1^{\text {st }} 2001$. President Chen Shuibian often used the US President as an example to exert influence in the appointment of personnel in the Executive Yuan, which showed his intention to pull the system towards a US-style presidential system. However, countries such as Australia, Ireland, Singapore and Portugal all directly elect their President, yet none of their systems can be defined as presidential, and Taiwan does not have a presidential system formally established by its constitution either.

5. Maurice Duverger, "A New Political System Model: Semi-Presidential Government", European Journal of Political Research, No. 2, Vol. 8, June, 1980, p. 166.

6. Maurice Duverger notes that, in countries that are semi-presidential in essence, there is a diversity of semi-presidential practices. That is why we devote our efforts to analysing what variables have led to a different operation among similar semipresidential systems. Other scholars, such as Shugart \& Carey, Presidents and Assemblies: Constitutional Design and Electoral Dynamics (1992), Robert Eligie in Semi-Presidentialism in Europe (1999), have also discussed different practices of semi-presidentialism around the world. Robert Eligie has attempted to define the concept of semi-presidentialism via three approaches. Firstly, semi-presidentialism is said to be a type of democratic regime where executive power is divided between a President and a Prime Minister but where the President has substantial powers. It also concerns specific constitutional arrangements with actual powers as Maurice Duverger has specified. Further, semipresidentialism can be simply a type of regime with dispositional properties in which a popularly-elected, fixed-term President exists alongside a Prime Minister and cabinet who are responsible to Parliament, regardless of how powerful a president is ("Semipresidentialism: Concepts, Consequences and Contesting Explanations", October 24th-25th 2003, Institute of Political Science, Academia Sinica, Taipei, Taiwan, pp. 4-7). 7. Taiwan is most likely to be included in the third type of semi-presidentialism under this category elaborated by Eligie.

8. ROC Constitution amendment, Article 2: Presidential orders to appoint or remove from office the Premier or personnel appointed with the confirmation of the Legislative Yuan in accordance with the Constitution, and to dissolve the Legislative Yuan, shall not require the countersignature of the Premier.

9. Fifth Republic Constitution, Article 8.

10. The confidence vote requires absolute majority support in the Parliament. Any coalition of opposition force against the Prime Minister can easily defeat it. During the first cohabitation, leftist President Mitterrand nominated the rightist Jacques Chirac as Prime Minister, who, immediately after entering office requested a vote of confidence. The result was positive with 292 in support and 285 against, strengthening the leadership of Chirac in the cohabitation and counterbalancing his power with that of Mitterrand. See Jean-Louis Thiébault, "France: Cabinet Decision-Making under the Fifth Republic", in Jean Blondel and F. Muller-Rommel (eds.), Cabinets in Western Europe, New York, St. Martin's Press, 1997, pp. 108-109.

11. Although both the French and Taiwan Constitutions state that the Premier is responsible before Parliament, in France this often means that the Prime Minister, although appointed by the President, must represent the parliamentary majority. In 
Taiwan, the Premier might not be expected to represent the parliamentary majority; his or her role might resemble more the role of the "chief of staff" in the US presidential system.

12. This point shows the main gap between the Constitution and constitutional practice.

13. Amendment article 3: With the signatures of more than one-third of the total number of Legislative Yuan members, the Legislative Yuan may propose a noconfidence vote against the Premier. The Premier shall tender his resignation within ten days and at the same time may request that the President dissolve the Legislative Yuan.

14. Fifth Republic Constitution, Article 12: The President, upon consultation with the Prime Minister and chairmen of the two chambers, can dissolve the Parliament.

15. In the complex relationship between the President, the Executive and the Legislature throughout the French history, there is a constitutional custom worth mentioning. On June 25th 1877, President Mac-Mahon dissolved Parliament with the intention of changing the majority composition of the Parliament and nominating a Prime Minister of his own preference. However, the dissolution of the Parliament leaded ultimately to the same composition of parties and subsequently to Mac-Mahon's resignation. The Mac-Mahon case created a constitutional routine for France: "if not accepting the majority in Parliament, a President shall then resign". Such constitutional routine cannot be found in Taiwan, reducing the likelihood of cohabitation.

16. The current term for a legislator is three years, which may also influence cost considerations. Yet, this might not be the main reason which results in unfunctionality of the no-confidence vote. Worth mentioning is that in a near future with the new electoral rule for the next term legislative election, namely a four-year term and the single member district method, the cost of re-election might face more uncertainty. 17. Gary W. Cox and Frances Rosenbluth, "The Electoral Fortunes of Legislative Factions in Japan", American Political Science Review, No. 87, 1993, p. 579.

18. Wang Yeh-lih, "The Political Consequences of the Electoral System: Single Non Transferable Voting in Taiwan", Issues \& Studies, August 1996. p. 96. Wang also points out that under SNTV, party identification is less important unless there is only one candidate in the district. More emphasis has been made on individual candidates when a party has many candidates competing in the same district.

19. See Yang James Jih-Ching, "Effects of Constitutional Amendment and Party Reorganization on Constitutional Framework", Theory and Policy, July 2000, Vol. 54, pp. 199-218 (in Chinese).

20. Melody Chen, "Social alliance pushes for two vote election system", Taipei Times, August 19th 2003. In this report, Chien Hsi-chieh, a DPP lawmaker and executive director of the Peacetime Foundation of Taiwan, cited a recent survey that revealed the average cost a legislative candidate has to spend during a single election amounts to NT\$42 million". A legislator's pay during his or her term totals, at most, NT\$20 million, Chien said.

21. Despite the fact that the no-confidence vote in Taiwan has never been used, President Chen, after experiencing much legislative gridlock, has begun to consult the opinions of the opposition party in the Legislative Yuan. The recent 10 points consensus reached by Chen Shui-bian and Soong Chu-yu exemplifies such an attempt. 
Therefore, whether a no-confidence vote will be triggered and effect a lessening of the power of the President remains uncertain and requires further observation.

22. A popular Chinese saying goes, "No two suns in the sky, no two rulers for a nation". 23. From 1949 when the KMT government moved to Taiwan, until 1987, due to martial law, the Constitution did not operate.

24. Chang Chun-hsiung, "Can we only expect 'charisma' without making any mistakes? Revise the Constitution but watch out for the turbulence that may result", Lianhe bao (United Daily News), May 13th 1997, p. 15.

\section{RÉSUMÉS}

After the Legislative Yuan elections in December 2004, Taiwan's political arena was, once again, echoing with recurring calls for French-style political cohabitation. Despite the similarity with the French constitutional system, the two systems differ in the gap between what is written in the Constitution in Taiwan and what is practiced. Why did cohabitation not occur in Taiwan? What has prevented cohabitation since President Chen Shui-bian's election victory in 2000? This article sets out to analyse the above questions by comparing the ways in which Taiwan drafts its constitutional rules with those used in France. And special attention is paid to the gap between constitutional norms and principles and the application of the constitution in practice. 